\title{
Analisis Kemampuan Menyusun Perangkat Pembelajaran Mahasiswa Universitas Qomaruddin Ditinjau Dari TPACK
}

\author{
Roisatun Nisa ${ }^{\prime 1^{*}}$, Nailil Faroh ${ }^{2}$ \\ ${ }^{1}$ Pendidikan Matematika, Universitas Qomaruddin, Gresik, Indonesia; \\ *roisatunnisa@uqgresik.ac.id \\ ${ }^{2}$ Pendidikan Matematika, Universitas Qomaruddin, Gresik, Indonesia; \\ nafa.7elfati@gmail.com
}

\begin{abstract}
Abstrak. Pendidikan merupakan salah satu investasi terbesar, terutama untuk mempersiapkan keterampilan abad 21 yang menuntut untuk berpikir kritis, kreatif, kolaboratif, dan komunikatif yang dapat diwujudkan dalam pembelajaran matematika. Untuk mencapai tujuan tersebut diperlukan peran pendidik dalam perancangan kegiatan pembelajaran matematika. Technological Pedagogical Content Knowledge (TPACK) merupakan penggabungan pengetahuan teknologi, pedagogi, dan isi yang diterapkan sesuai dengan konteks. Oleh karena itu, mahasiswa calon guru dituntut untuk bisa mengintegrasikan teknologi ke dalam pembelajaran. Tujuan penelitihan ini adalah untuk mengetahui kemampuan mahasiswa dalam menyusun perangkat ditinjau dari TPACK. Penelitian ini merupakan penelitian deskriptif dengan pendekatan kuantitatif yang dilakukan di Universitas Qomaruddin dengan jumlah 24 Mahasiswa Prodi Pendidikan Matematika. Instrumen yang digunakan dalam penelitian ini berupa penilaian penyusunan Perangkat pembelajaran melalui Rencana pelaksanaan pembelajaran (RPP) Mahasiswa yang diuji reliabilitasnya kemudian ditabulasikan dan dideskripsikan. Hasil penelitian menunjukkan bahwa tingkat reliabilitas instrumen yang diperoleh adalah tinggi. Kemampuan mahasiswa dalam menyusun perangkat pembelajaran tergolong sangat baik, dengan skor Technological Knowledge (TK) sebesar 86,46\%, Pedagogical Knowledge (PK) sebesar 84,55\%, Content Knowledge (CK) sebesar 83,85\%, Technological Content Knowledge (TCK) sebesar 83,33\%, Pedagogical Conten Knowledge (PCK) sebesar 88,54\%, Technological Pedagogical Knowledge (TPK) sebesar 70,83\% dan TPACK sebesar $71,88 \%$.
\end{abstract}

Kata Kunci: RPP, Technological Pedagogical Content Knowledge (TPACK)

\begin{abstract}
Education is one of the biggest investments, especially to prepare 21st century skills that demand critical, creative, collaborative, and communicative which can be realized in learning mathematics. To achieve this goal, the role of teacher is required in designing mathematics learning activities. Technological Pedagogical
\end{abstract}


Content Knowledge (TPACK) learning based is a combination of technological knowledge, pedagogy, and content that is applied in accordance with the context. Therefore, undergraduate teacher candidates are required to be able to integrate technology into learning. The purpose of this research was to find out the ability of students in arranging devices based on TPACK. This research was a descriptive study with a quantitative approach conducted at the Universitas Qomaruddin with a total of 24 Mathematics Education Study Program undergraduate students. The instrument applied in this study was the assessment of the lesson plans which were tested for its reliability, tabulated and described. The results showed that the reliability level of the instrument was high. The ability of students in compiling learning tools is very good, with a score of $86.46 \%$ Technological Knowledge (TK), 84.55\% Pedagogical Knowledge (PK), 83.85\% Content Knowledge (CK), Technological Content Knowledge (TCK) 83.33\%, Pedagogical Content Knowledge (PCK) 88.54\%, Technological Pedagogical Knowledge (TPK) 70.83\% and TPACK $71.88 \%$.

Keywords: Lesson Plan, Technological Pedagogical Content Knowledge (TPACK).

\section{Pendahuluan}

Dewasa ini teknologi tengah berkembang pesat dan dapat dijumpai di berbagai bidang, salah satunya bidang pendidikan. Pendidikan merupakan salah satu investasi terbesar, terutama untuk mempersiapkan keterampilan abad 21. Keterampilan abad 21 menuntut untuk berpikir kritis, kreatif, kolaboratif, dan komunikatif yang dapat diwujudkan dalam pembelajaran matematika. Untuk mencapai tujuan tersebut diperlukan peran pendidik dalam perancangan kegiatan pembelajaran matematika. Hal tersebut sejalan dengan capaian pembelajaran yang harus dimiliki oleh pendidik jenjang sarjana, yakni mampu merencanakan, melaksanakan dan mengevaluasi pembelajaran dengan pendekatan pembelajaran yang berpusat pada siswa dengan memanfaatkan berbagai sumber belajar, media pembelajaran berbasis ipteks sesuai standar proses dan mutu (Indonesia, 2019).

Hal ini juga dijelaskan dalam Undang-Undang Republik Indonesia Nomor 14 Tahun 2005 tentang Guru dan Dosen (Sarp, 2005) menyatakan bahwa Seorang Guru harus memiliki 4 Kompetensi yakni kompetensi Kepribadian, Sosial, Pedagogis dan Profesional. Kompetensi kepribadian mencakup kemampuan personal yang berwibawa dan berkarakter sebagai guru. Kemampuan sosial mencakup kemampuan guru berinteraksi dengan peserta didik, guru ataupun tenaga kependidikan, wali peserta didik, serta masyarakat sekitar. Selanjutnya kemampuan Pedagogis mencakup kemampuan guru dalam mengelola Copyright (C) 2021

Buana Matematika :

Jurnal Ilmiah Matematika dan Pendidikan Matematika 
pembelajaran. Sedangkan kemampuan professional mencakup kemampuan guru dalam menguasai materi, penguasaan ilmu pengetahuan, teknologi, seni maupun budaya.

Sejalan(Permenristekdikti No. 55, 2017) tentang pendidikan guru yang bertujuan untuk menghasilkan guru sebagai pendidik profesional yang nasionalis dan memiliki wawasan global sesuai dengan kebutuhan nasional, lokal, dan atau perkembangan ilmu pengetahuan, teknologi, dan seni. Hal tersebut menjadi tantangan berat bagi Lembaga Pendidikan Tinggi Keguruan dalam mempersiapkan mahasiswa calon guru untuk menjadi guru masa kini dan masa depan. Apalagi dalam konteks global juga berkembang suatu bentuk pola pengembangan kompetensi guru yang disebut dengan TPACK atau Technological, Pedagogical, Content Knowledge yang intinya seorang guru harus memiliki pengetahuan dan keterampilan yang kemprehensif dan holistic dalam hal materi/ konten, pedagodik/ ilmu mendidik serta teknologi(Rafi \& Sabrina, 2019)

(Koçoğlu, 2009) menyatakan bahwa TPACK merupakan bagian dasar dari mengajar yang efektif dengan teknologi, memerlukan pemahaman tentang representasi dari konsep-konsep yang menggunakan teknologi; teknik pedagogis yang menggunakan teknologi untuk mengajarkan materi/konten; pengetahuan tentang apa yang membuat konsep-konsep sulit atau mudah untuk belajar dan bagaimana teknologi dapat membantu memperbaiki beberapa masalah yang dihadapi siswa; dan pengetahuan tentang bagaimana teknologi dapat digunakan untuk membangun pengetahuan untuk mengembangkan metode/cara-cara baru atau memperkuat yang lama.

TPACK yang dimiliki mahasiswa memiliki peranan yang sangat penting karena akan mempengaruhi cara mengajar mahasiswa. Dengan adanya perangkat pembelajaran, secara sistematis calon guru dapat mewujudkan proses pembelajaran yang efektif dan dapat memenuhi kebutuhan belajar siswa (Barata, 2015).

Oleh karena itu, mahasiswa calon guru dituntut untuk bisa mengintegrasikan teknologi ke dalam pembelajaran. Hal tersebut sangat dibutuhkan terutama pada masa pandemi, dimana siswa dituntut belajar di rumah masing-masing secara daring, hal ini menuntut mahasiswa sebagai calon guru bisa memanfaatkan berbagai teknologi yang ada guna tercapainya pembelajaran peserta didik. Selain itu, dibutuhkan sebuah pendekatan yang memberlakukan mengajar sebagai interaksi antara apa yang guru ketahui dan Copyright (C) 2021

Buana Matematika :

Jurnal Ilmiah Matematika dan Pendidikan Matematika

p-ISSN : 2088-3021 e-ISSN : 2598-8077 
bagaimana mereka menerapkan apa yang mereka ketahui dalam keadaan yang menarik sesuai dengan pengetahuan mereka. Tidak ada "satu cara terbaik" untuk mengintegrasikan teknologi ke dalam kurikulum. Sebaliknya, upaya integrasi harus dirancang dengan kreatif atau terstruktur untuk mata pelajaran tertentu dan ide-ide penting dalam konteks kelas tertentu(Koehler et al., 2013)

Matematika merupakan salah satu dari mata pelajaran abstrak, yang sulit untuk dipahami oleh siswa, Penyajian materi menuntut kemampuan calon guru untuk mengorganisasi isi pelajaran sebagai persiapan untuk membangun pengetahuan siswa. Oleh sebab itu diperlukan bentuk pembelajaran yang dapat menggambarkan proses yang terjadi pada materi yang telah ditentukan. Sehingga sebagai calon guru haruslah benar-benar memahami kognisi dan berbagai cara yang berbeda dalam belajar. Calon guru haruslah pula memahami perkembangan siswa dan berbagai konsep pedagogik sebaik mereka menguasai materi pembelajaran dan penilaian alternatif yang digunakannya untuk mengukur hasil belajar siswa. Dengan demikian, calon guru harus mampu menempatkan berbagai substansi perbedaan bahasa dan budaya, gaya belajar, talenta, dan intelegensi sebagai dasar dalam melaksanakan berbagai strategi pengajaran yang dipilihnya(Lestari, 2015). Sehingga dalam mata kuliah perencanaan pembelajaran matematika mahasiswa dibekali kemampuan menyusun dan memprektekkan perangkat pembelajarannya

Berdasarkan kondisi di atas, pembelajaran haruslah dilaksanakan atas dasar apa yang diketahui dan dapat dilakukan siswa sebagaimana siswa berpikir dan belajar untuk menyelaraskan proses belajar dengan performa yang dibutuhkan sejalan dengan kebutuhan individu siswa. Melihat kenyataan ini, jelaslah mahasiswa calon guru harus benar-benar memiliki karakteristik unggul sehingga ia akan dapat melaksanakan misi barunya dalam proses pendidikan. Penciptaan guru berkarakteristik unggulan ini haruslah dilakukan baik pada saat guru menempuh proses pendidikan keguruan maupun pada saat guru sudah melaksanakan jabatannya sebagai tenaga pendidik (Lestari, 2015).

Oleh karena itu, penulis mengangkat tema permasalahan mengenai analisis kemampuan menyusun perangkat pembelajaran mahasiswa Universitas Qomaruddin ditinjau dari TPACK.

Copyright $@ 2021$

Buana Matematika :

Jurnal Ilmiah Matematika dan Pendidikan Matematika 


\section{Metode}

Penelitian ini merupakan penelitian deskriptif dengan pendekatan kuantitatif. Penelitian ini dilakukan di Universitas Qomaruddin dengan jumlah 24 Mahasiswa Prodi Pendidikan Matematika yang telah menempuh mata kuliah Perencanaan Pembelajaran Matematika. Data yang digunakan dalam penelitian ini berupa penilaian penyusunan Perangkat pembelajaran melalui RPP Mahasiswa. Adapun kisi-kisi lembar penilaiannya diadopsi dari (Hidayani, 2017).

Berikut Tabel 1. Kisi-kisi lembar penilaian

\begin{tabular}{|c|c|c|}
\hline Pengetahuan & Aspek & Sub Aspek \\
\hline $\begin{array}{l}\text { Technological } \\
\text { Knowledge (TK) }\end{array}$ & A. Penggunaan Teknologi & 1. Penggunaan Teknologi \\
\hline \multirow{7}{*}{$\begin{array}{c}\text { Pedagogical } \\
\text { Knowledge (PK) }\end{array}$} & \multirow{2}{*}{$\begin{array}{l}\text { A. Pengetahuan Strategi } \\
\text { Pembelajaran }\end{array}$} & $\begin{array}{l}\text { 1. Penggunaan Pendekatan } \\
\text { pembelajaran }\end{array}$ \\
\hline & & $\begin{array}{l}\text { 2. Penggunaan Metode dan } \\
\text { Model Pembelajaran }\end{array}$ \\
\hline & \multirow{2}{*}{$\begin{array}{l}\text { B. Pengetahuan Media } \\
\text { Pembelajaran }\end{array}$} & $\begin{array}{l}\text { 1. Penggunaan Media } \\
\text { Pembelajaran }\end{array}$ \\
\hline & & 2. Jenis Media Pembelajaran \\
\hline & \multirow{3}{*}{ C. Pengetahuan Evaluasi } & 1. Ranah penilaian \\
\hline & & 2. Pemilihan teknik Penilaian \\
\hline & & $\begin{array}{l}\text { 3. Kesesuaian dan perbaikan } \\
\text { penilaian }\end{array}$ \\
\hline \multirow{4}{*}{$\begin{array}{c}\text { Content } \\
\text { Knowledge (CK) }\end{array}$} & \multirow{4}{*}{$\begin{array}{l}\text { A. Pengetahuan Konsep } \\
\text { Materi }\end{array}$} & 1. Keluasan Materi \\
\hline & & 2. Kedalaman Materi \\
\hline & & 3. Kesesuaian Materi \\
\hline & & 4. Pengembangan Materi \\
\hline $\begin{array}{l}\text { Technological } \\
\text { Content } \\
\text { Knowledge } \\
\text { (TCK) }\end{array}$ & $\begin{array}{l}\text { A. Pengintegrasian } \\
\text { pengetahuan konten } \\
\text { dengan teknologi }\end{array}$ & $\begin{array}{l}\text { 1. Pengintegrasian } \\
\text { pengetahuan konten dan } \\
\text { teknologi dalam } \\
\text { pembelajaran }\end{array}$ \\
\hline $\begin{array}{l}\text { Pedagogical } \\
\text { Content } \\
\text { Knowledge } \\
\text { (PCK) }\end{array}$ & $\begin{array}{ll}\text { A. } & \text { Pengintegrasian } \\
& \text { Pendekatan } \\
& \text { Pembelajaran dengan } \\
\text { konten pembelajaran }\end{array}$ & $\begin{array}{l}\text { 1. Pengintegrasian Pendekatan } \\
\text { Pembelajaran dengan konten } \\
\text { dalam pembelajaran }\end{array}$ \\
\hline $\begin{array}{l}\text { Technological } \\
\text { Pedagogical } \\
\text { Knowledge } \\
\text { (TPK) }\end{array}$ & $\begin{array}{l}\text { A. Pengintegrasian } \\
\text { teknologi dan strategi } \\
\text { pembelajaran }\end{array}$ & $\begin{array}{l}\text { 1. Pengintegrasian teknologi } \\
\text { dan strategi dalam } \\
\text { pembelajaran }\end{array}$ \\
\hline
\end{tabular}




\begin{tabular}{|c|c|c|}
\hline Pengetahuan & Aspek & Sub Aspek \\
\hline $\begin{array}{c}\text { Technological } \\
\text { Pedagogical And } \\
\text { Content } \\
\text { Knowledge } \\
\text { (TPACK) }\end{array}$ & $\begin{array}{l}\text { A. Pengintegrasian } \\
\text { teknologi, konten, dan } \\
\text { pendekatan } \\
\text { pembelajaran }\end{array}$ & $\begin{array}{l}\text { 1. Pengintegrasian teknologi, } \\
\text { konten, dan pendekatan } \\
\text { pembelajaran dalam kelas }\end{array}$ \\
\hline
\end{tabular}

Kisi-kisi penilaian diatas kemudian diuji reliabilitasnya menggunakan interrater reliability yaitu dilakukan oleh 2 orang rater atau obsever kemudian dihitung dengan menggunakan rumus Cohen Kappa (Boslaugh \& Watters: 2008). Rumus Cohen Kappa adalah sebagai berikut:

$K=\frac{P_{o}-P_{e}}{1-P_{e}}$

Keterangan:

$K=$ Moment Kappa

$P_{o}=\frac{A+D}{N}$

$P_{e}=\frac{A_{1}}{N} \frac{B_{1}}{N}+\frac{A_{2}}{N} \frac{B_{2}}{N}$

$1=$ Konstanta

$A_{1}, B_{1}, A_{2}, B_{2}$ dan $N$ dapat ditunjukkan pada tabel di bawah ini:

Tabel 2. Keterangan rumus Kappa

\begin{tabular}{|c|c|c|c|}
\hline \multirow{2}{*}{ Rater } & \multicolumn{2}{|c|}{ Rater 2 } & \multirow{2}{*}{$\sum$} \\
\cline { 2 - 4 } $\mathbf{1}$ & $\mathbf{1}$ & $\mathbf{2}$ & \\
\hline 1 & $A$ & $B$ & $B_{1}=A+B$ \\
\hline 2 & $C$ & $D$ & $B_{2}=C+D$ \\
\hline$\sum$ & $A_{1}=A+C$ & $A_{2}=B+D$ & $N$ \\
\hline
\end{tabular}

Selanjutnya, Momen Kappa (k) berkisar dari 0 sampai 1, dengan interpretasi menurut(Boslaugh, 2008) disajikan pada Tabel 3.

Tabel 3. Interpretasi nilai momen Kappa (k)

\begin{tabular}{|c|l|}
\hline Nilai $\boldsymbol{K}$ & \multicolumn{1}{|c|}{ Kategori } \\
\hline $0,81-1,00$ & Sangat Tinggi \\
\hline $0,61-0,80$ & Tinggi \\
\hline $0,41-0,60$ & Sedang \\
\hline $0,21-0,40$ & Rendah \\
\hline $0,00-0,20$ & Sangat Rendah \\
\hline$<0,00$ & Tidak Diperhitungkan \\
\hline
\end{tabular}

Copyright (C) 2021

Buana Matematika :

Jurnal Ilmiah Matematika dan Pendidikan Matematika 
Data yang sudah terkumpul kemudian ditabulasikan dan dideskripsikan. Langkah-langkah dalam mengolah data hasil penilaian perangkat adalah sebagai berikut (Sudijono, 2011):

a. Jenis data yang diambil berupa data kualitatif kemudian diubah menjadi nilai kuantitatif dengan ketentuan dapat dilihat dalam tabel 4 sebagai berikut:

Tabel 4. Aturan pemberian skala

\begin{tabular}{|l|c|l|}
\hline No. & Skor & Kategori \\
\hline 1 & 4 & Sangat baik \\
\hline 2 & 3 & Baik \\
\hline 3 & 2 & Kurang \\
\hline 4 & 1 & Sangat Kurang \\
\hline
\end{tabular}

b. Skor rata-rata dihitung untuk setiap aspek kriteria dan diubah dalam bentuk prosentase dengan menggunakan rumus:

$$
\begin{aligned}
& X=\frac{\sum x}{n} \times 100 \% \\
& \text { Keterangan: } \\
& X=\text { Skor rata }- \text { rata tiap aspek } \\
& \sum x=\text { Jumlah skor tiap aspek } \\
& n=\text { Jumlah Penilaian }
\end{aligned}
$$

c. Data yang diperoleh selanjutnya diubah dalam kriteria kualitatif pada tabel berikut:

Tabel 5. Rentang Persentase dan Kriteria Kualitatif

\section{Hasil dan Pembahasan}

\begin{tabular}{|c|c|}
\hline Rentang & Kriteria Kualitatif \\
\hline $0-20$ & Sangat Kurang \\
\hline $21-40$ & Kurang \\
\hline $41-60$ & Cukup \\
\hline $61-80$ & Baik \\
\hline $81-100$ & Sangat Baik \\
\hline
\end{tabular}

\section{Uji Reliabilitas Instrumen}

Berdasarkan hasil penelitian yang telah dilakukan peneliti, Hal pertama yang dilakukan peneliti adalah uji reliabilitas instrumen kepada dua Rater. Dua rater yang dimaksud disini adalah akademisi sekaligus dosen dengan bidang keahlian Pendidikan Matematika. Adapun Skor yang diperoleh dari dua rater tersebut adalah sebagai berikut. 
Tabel 6. Penilaian Dua Rater

\begin{tabular}{|c|c|c|c|}
\hline \multirow{2}{*}{ Rater } & \multicolumn{2}{|c|}{ Rater 2 } & \multirow{2}{*}{$\Sigma$} \\
\cline { 2 - 3 } $\mathbf{1}$ & $\mathbf{1}$ & $\mathbf{2}$ & \\
\hline 1 & 6,25 & 0 & $B_{1}=6,25$ \\
\hline 2 & 6,25 & 87,5 & $B_{2}=93,75$ \\
\hline$\sum$ & $A_{1}=12,5$ & $A_{2}=87,5$ & 100 \\
\hline
\end{tabular}

Berdasarkan tabel di atas, terlihat bahwa terdapat $14(87,5 \%)$ aspek yang dinilai konsisten. Terdapat $1(6,25 \%)$ aspek yang sama sama dinilai tidak setuju. Dan 1 (6,25\%) aspek dinilai berbeda, rater 1 menilai setuju dan rater 2 menilai tidak setuju. Dengan menggunakan rumus Kohen Cappa, maka hasil uji reliabilitasnya adalah 0,63 . Hal ini mengindikasikan bahwa tingkat reliabilitas instrumen yang diperoleh adalah tinggi. Oleh karena itu, instrumen yang digunakan dalam penelitian ini dinyatakan reliabel. Hal ini sejalan dengan penelitian Napitupulu, bahwasanya koefisien Kappa dapat diintepretasikan dalam kategori memuaskan, karena nilai kategori kappa $\mathrm{k}>0,60$. Dengan demikian terdapat kesepakatan antar ahli yang baik, sehingga instrumen tersebut dikatakan valid dan reliabel.(Napitupulu, 2015)

\section{Analisis Kemampuan Mahasiswa dalam menyusun perangkat ditinjau dari TPACK}

Langkah selanjutnya setelah instrumen dinyatakan reliabel adalah analisis Rencana Pelaksanaan Pembelajaran (RPP) dari 24 mahasiswa prodi Pendidikan Matematika Universitas Qomaruddin. Adapun hasil analisisnya secara garis besar dapat dilihat pada gambar berikut.

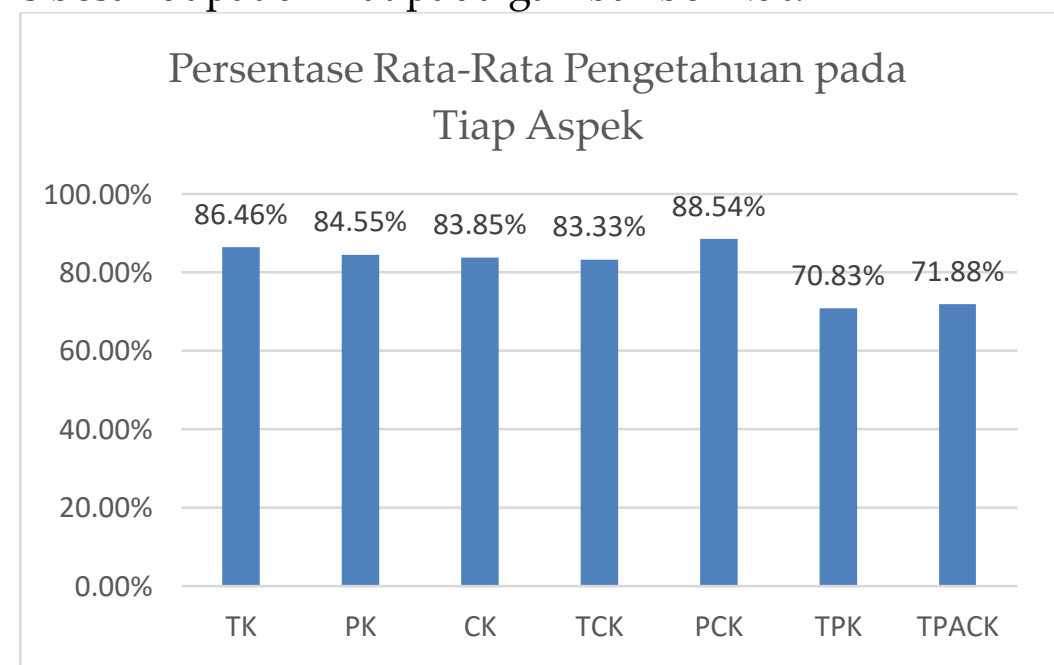

Gambar 1. Persentase rata-rata pengetahuan pada tujuh aspek

Copyright $(0) 2021$

Buana Matematika :

Jurnal Ilmiah Matematika dan Pendidikan Matematika 
Dari gambar di atas, akan dijelaskan pada setiap aspek berikut ini.

\section{Technological Knowledge (TK)}

Technological Knowledge (TK) atau lebih dikenal dengan pengetahuan terkait teknologi merupakan salah satu unsur penting bagi calon guru. Mahasiswa calon guru harus melek teknologi. Apalagi teknologi pendidikan di masa pandemi ini sangat diperlukan bagi seluruh akademisi. Situasi ini memaksa adanya peningkatan secara cepat dan luas dari penggunaan teknologi.

Data hasil analisis kemampuan Content Knowledge pada 24 mahasiswa didapatkan rata rata sebesar 86,46 \% dengan kategori sangat baik. Kemampuan terhadap penguasaan pengetahuan teknologi mahasiswa terlihat bahwa 91\% RPP mahasiswa di dalamnya sudah menggunakan tegnologi dalam konteks Pendidikan. Diantaranya adalah mahasiswa menerapkan pembelajaran menggunakan Google Classroom, Microsoft teams atau Moodle, dan sebagainya.

\section{Pedagogical Knowledge (PK)}

Pedagogical Knowledge mendeskripsikan tentang pengetahuan terkait pendekatan, model, metode, strategi, media dan evaluasi dalam pembelajaran. Dari hasil analisis RPP yang telah dilakukan, mahasiswa calon guru menggunakan pendekatan, model, metode, strategi, dan media yang berbeda beda. Kemampuan Pedagogical Knowledge juga bisa dilihat ketika mahasiswa mampu mengelola dan mengorganisir siswa dalam aktivitas pembelajaran.

Pada aspek pengetahuan strategi pembelajaran, mempunyai skor rata-rata 91,15\%. Rata-rata aspek pengetahuan media pembelajaran adalah 78,13\% dan rata-rata aspek pengetahuan evaluasi adalah $84,38 \%$. Hal ini menunjukkan bahwa rata-rata kemampuan dalam menguasai pembelajaran adalah $84,55 \%$ dengan kategori sangat baik.

\section{Content Knowledge (CK)}

Content Knowledge yang dimaksud dalam penelitian ini adalah pengetahuan konsep materi mahasiswa terkait keluasan dan kedalaman materi matematika. Pengembangan dan kesesuaian materi dalam hal ini juga sangat penting, karena mahasiswa calon guru harus memiliki kompetensi professional. Data hasil analisis Content Knowledge dari 24 mahasiswa memiliki skor rata-rata $83,85 \%$ dengan kategori sangat baik. Hal ini karena mahasiswa dibekali mata kuliah matematika sekolah 1 dan 2 yakni mencakup 
materi matematika tingkat dasar dan menengah, sehingga mahasiswa mampu menguasai materi dengan sangat baik.

\section{Technological Content Knowledge (TCK)}

Technological Content Knowledge (TCK) mendiskripsikan kemampuan mahasiswa calon guru dalam materi matematika dan mampu mengitegrasikan materi ke dalam teknologi dalam pembelajaran, baik pembelajaran daring maupun luring. Dalam hal ini, terdapat 83,33\% mahasiswa mampu mengitegrasikan materi dengan teknologi dalam pembelajaran.

\section{Pedagogical Content Knowledge (PCK)}

Sebagai mahasiswa calon guru, dengan adanya mata kuliah bidang pendidikan terkait model pembelajaran, maupun administrasi dalam pembelajaran, mahasiswa diharapkan mampu memilah pendekatan maupun model pembelajaran disesuaikan dengan materi yang telah ditetapkan. Materi yang dimaksud disini adalah materi matematika tingkat dasar atau menengah. Mahasiswa menggunakan beberapa model pembelajaran antara lain adalah model Problem Based Learning, Cooperative Learning, Project Based Learning. Sedangkan beberapa pendekatan diantaranya adalah Pendekatan saintifik, Quantum Teaching Learning, Realistic Mathematics Education, dan lain sebagainya. Sehingga, berdasarkan hasil analisisnya menunjukkan bahwa Pedagogical Content Knowledge (PCK) mahasiswa calon guru sebesar 88,54\%.

\section{Technological Pedagogical Knowledge (TPK)}

Technological Pedagogical Knowledge (TPK) merupakan pengintegrasian tekhnologi dan strategi dalam pembelajaran. Dalam hal ini, sebanyak 70,83\% mahasiswa sudah menggunakan tekhnologi dan strategi dalam pembelajaran. Adapun tekhnologi pembelajaran yang digunakan selama daring, diantaranya adalah Google Classroom, Microsoft Teams, Edmodo, Zoom, Google Meet, E-learning Kemenag dan lain sebagainya. Penggunaan strategi pembelajaran juga tidak bisa lepas dari penggunaan tekhnologi tersebut, sebagai contoh yang telah dilakukan oleh mahasiswa adalah ketika menggunakan Google Meet, Mahasiswa memberikan materi persamaan trigonometri pada siswa kelas XI IPA, Selanjutnya secara acak, mahasiswa calon guru menunjuk salah satu siswa untuk menjawab pertanyaan yang

Copyright (C) 2021

Buana Matematika :

Jurnal Ilmiah Matematika dan Pendidikan Matematika 
diberikan. Dengan strategi tersebut, meskipun pembelajaran daring, siswa tetap menyimak materi yang telah diberikan.

\section{Technological Pedagogical And Content Knowledge (TPACK)}

Technological Pedagogical and Content Knowledge (TPACK) merupakan pengetahuan tentang domain prinsip pengetahuan (konten, pedagogi, teknologi) yang tidak dapat terpisahkan. Untuk menjadi calon guru yang profesional, mahasiswa dituntut untuk mampu mengintegrasikan tiga prinsip pengetahuan tersebut. Selain mahasiswa memahami isi materi matematika, mahasiswa mampu menggunakan beberapa media pembelajaran interaktif, serta mampu menerapkan model/strategi dalam pembelajaran meskipun pada saat ini sistem pembelajarannya secara daring. Hal ini dapat dibuktikan dari analisis TPACK bahwasanya terdapat $71,88 \%$ mahasiswa mengintegrasian teknologi, konten, dan pendekatan pembelajaran dalam kelas. Hal ini sesuai dengan penelitian (Suyamto et al., 2020) yang menyatakan bahwa TPACK berdampak pada guru mengingat hubungan teknologi, pedagogi, dan konten tidak dapat dipisahkan. Sehingga guru akan menghadapi lebih besar tantangan di masa mendatang dan berbanding lurus dengan perkembangan teknologi. Guru harus aktif dalam pengembangan dan desain pembelajaran maupun kurikulum.

\section{Simpulan}

Berdasarkan hasil analisis kemampuan TPACK 24 mahasiswa Prodi Pendidikan matematika Universitas Qomaruddin dapat disimpulkan bahwa kemampuan mahasiswa dalam menyusun perangkat pembelajaran tergolong sangat baik, dengan skor Technological Knowledge (TK) sebesar 86,46\%, Pedagogical Knowledge (PK) sebesar 84,55\%, Content Knowledge (CK) sebesar 83,85\%, Technological Content Knowledge (TCK) sebesar 83,33\%, Pedagogical Conten Knowledge (PCK) sebesar 88,54\%, Technological Pedagogical Knowledge (TPK) sebesar $70,83 \%$ dan TPACK sebesar 71,88\%. Untuk mampu mengintegrasikan tekhnologi, materi, dan kemampuan mengajar, diperlukan TPACK khususnya untuk mahasiswa calon guru, sehingga nantinya harapan peneliti, mahasiswa menjadi guru yang profesional dan mampu bersaing di era industry 4.0 .

\section{Ucapan Terima Kasih}

Ucapan terima kasih kami sampaikan kepada semua pihak yang telah membantu dalam penyelesaian artikel ilmiah ini, khususnya kepada Direktorat Riset dan Pengabdian Masyarakat, Direktorat Jenderal Riset dan Copyright (C) 2021

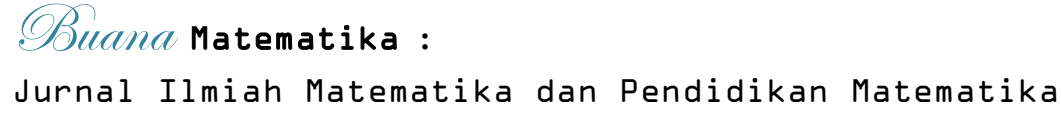


Pengembangan Kementrian Riset, teknologi dan Pendidikan Tinggi yang telah dalam hal pendanaan penelitian. Semoga penelitian ini dapat dikembangkan dan bisa bermanfaat kedepannya.

\section{Daftar Pustaka}

Barata, A. (2015). Pengembangan perangkat pembelajaran matematika pada materi perbandingan untuk siswa kelas VII dengan pendekatan kontekstual.

Boslaugh, S. (2008). Statistics in a Nutshell.

Hidayani, N. (2017). Kemampuan Technological Pedagogical Content. Skripsi. Indonesia, M. R. T. dan P. T. R. (2019). Peraturan Menteri Riset, Teknologi, dan Pendidikan Tinggi Republik Indonesia. Kemenristekdikti, 1-58.

Koçoğlu, Z. (2009). Exploring the technological pedagogical content knowledge of pre-service teachers in language education. Procedia-Social and Behavioral Sciences, 1(1), 2734-2737. https://doi.org/10.1016/j.sbspro.2009.01.485

Koehler, M. J., Mishra, P., \& Cain, W. (2013). What is Technological Pedagogical Content Knowledge (TPACK)? Journal of Education, 193(3), 13-19. https://doi.org/10.1177/002205741319300303

Lestari, S. (2015). Analisis Kemampuan Technological Pedagogical Content Knowledge (TPACK) pada Guru Biologi SMA dalam Materi Sistem Saraf. Seminar Nasional XII Pendidikan Biologi FKIP UNS 2015, 1(1), 123-136.

Napitupulu, D. B. (2015). Studi Validitas Dan Realibilitas Faktor Sukses Implementasi E-Government Berdasarkan Pendekatan Kappa. Jurnal Sistem Informasi, 10(2), 71. https://doi.org/10.21609/jsi.v10i2.388

Permenristekdikti No. 55. (2017). Peraturan Menteri Riset, Teknologi dan Pendidikan Tinggi tentang Standar Pendidikan Guru. 10.

Rafi, I., \& Sabrina, N. (2019). Pengintegrasian TPACK dalam Pembelajaran Geometri SMA untuk Mengembangkan Profesionalitas Guru Matematika. SJME (Supremum Journal of Mathematics Education), 3(1), 4756. https://doi.org/10.31235/osf.io/v2ygb

Sarp, G. (2005). No 主観的健康感を中心とした在宅高龄者における健康関連 指標に関する共分散構造分析Title. March, 25-27.

Sudijono, A. (2011). Pengantar Statistik Pendidikan. In Anas Sudijono (27th ed.). RajaGrafindo Persada (Rajawali Press).

Sugiyono. (2019). Metode Penelitian Pendidikan Pendekatan Kuantitatif, Kualitatif, dan $R \mathcal{E} D$ (2nd ed.). Alfabeta.

Suyamto, J., Masykuri, M., \& Sarwanto, S. (2020). Analisis Kemampuan Tpack (Technolgical, Pedagogical, and Content, Knowledge) Guru Biologi Sma

Copyright $@ 2021$

Buana Matematika :

Jurnal Ilmiah Matematika dan Pendidikan Matematika 
Dalam Menyusun Perangkat Pembelajaran Materi Sistem Peredaran Darah. INKUIRI: Jurnal Pendidikan IPA, 9(1), 46. https://doi.org/10.20961/inkuiri.v9i1.41381

\section{Riwayat Hidup Penulis}

\section{Roisatun Nisa'}

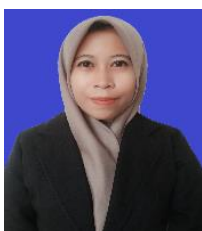

Lahir di Gresik, 20 Januari 1990. Staf pengajar di Universitas Qomaruddin. Studi S1 Pendidikan Matematika Universitas PGRI Adibuana Surabaya, Lulus Tahun 2012; S2 Pendidikan Matematika Universitas Negeri Surabaya, Lulus tahun 2015.

\section{Nailil Faroh}

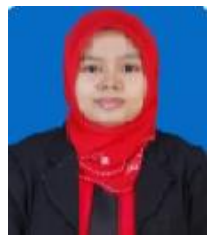

Lahir di Pati, 01 Maret 1989. Staf pengajar di Universitas Qomaruddin. Studi S1 Pendidikan Matematika IAIN Walisongo Semarang, Lulus Tahun 2011; S2 Pendidikan Matematika Universitas Negeri Semarang, Lulus tahun 2014. 
Jurnal Ilmiah Matematika dan Pendidikan Matematika Vol. 11 No. 1 (2021)

Copyright (C) 2021

Buana Matematika :

Jurnal Ilmiah Matematika dan Pendidikan Matematika 